\title{
PENDAMPINGAN DAN PENINGKATAN KAPASITAS DAN KUALITAS PRODUKSI JAMU YANG BERBASIS GREEN SYSTEM
}

\author{
Dr. Isfenti Sadalia ${ }^{1}$, Beby Kendida Hasibuan ${ }^{2}$, Imam Bagus Sumatri $^{3}$ \\ ${ }^{1}$ Fakultas Ekonomi dan Bisnis Universitas Sumatera Utara \\ isfentisadalia@gmail.com \\ ${ }^{2}$ Fakultas Ekonomi dan Bisnis Universitas Sumatera Utara \\ bebykendida08@gmail.com \\ ${ }^{3}$ Fakultas Farmasi Universitas Sumatera Utara \\ ibs2342@gmail.com
}

\begin{abstract}
Abstrak
Jamu merupakan warisan dari budaya Indonesia. Dimana sejak jaman dahulu sampai sekarang penggunaan jamu masih menjadi alternative pengobatan diminati oleh masyarakat Indonesia. Tujuan utama pengabdian kepada masyarakat ini adalah meningkatkan kapasitas dan kualitas produksi jamu agar dapat meningkatkan produksi jamu tersebut dan juga dapat meningkatkan kualitas dari jamu tersebut. Sehingga produksi dan kuliatas jamu yang dimiliki mitra akan dapat bersaing dengan jamujamu milik pabrikan. Mitra akan diajari cara penggunaan teknologi yang tepat dalam memperoduksi jamu dengan kapasitas yang lebih besar serta menghasilkan jamu dengan kualitas terbaik dan juga higienis. Selain itu mitra juga akan diberikan pengetahuan dan didampingi dalam hal pengemasan yang baik dan menarik. Hal ini dilakukan untuk dapat meningkatkan volume penjualan dari produk jamu tersebut. Kegiatan ini diharapkan dapat membantu mitra dalam meningkatkan kapasitas produksi dan juga membantu mitra dalam meningkatkan volume penjualan.
\end{abstract}

Keyword : peningkatan, kualitas produksi, kapasitas, dan jamu

\section{Abstract}

Herbal medicine is the cultural heritage of Indonesia. Which since antiquity to the present use of herbs as an alternative treatment still in demand by the people of Indonesia. The main purpose of community service is to improve the capacity and quality of herbal medicine production in order to increase production of herbal medicine and can also improve the quality of these herbs. So the production and quality of herbs will be able to compete with the other factory nostrum. Partners will be taught how to use appropriate technology in produce herbs with greater capacity and produce herbal medicine with the best quality and also hygienic. Furthermore partners will also be given the knowledge and assisted in terms of good and attractive packaging. This is done in order to increase the volume of sales of the medicinal product. This activity is expected to assist partners in increasing production capacity and also helps partners to increase sales volume.

Keyword : enhancement, production quality, capacity, and herbal medicine

\section{PENDAHULUAN}

\section{Analisi Situasi}

Indonesia merupakan salah satu negara dengan kekayaan alam berupa kekayaan hayati yang sangat beragam. Masyarakat Indonesia sejak dahulu kala banyak memanfaatkan kekayaan alam hayati berupa tumbuh-tumbuhan sebagai obat penyembuh untuk beberapa penyakit yang dewasa ini kita kenal dengan nama jamu atau obat herbal. Antara lain batuk, flu, demam, dan lain-lain. Obat herbal atau herbal medicine didefinisikan sebagai bahan baku atau sediaan yang berasal dari tumbuhan yang memiliki efek terapi atau efek lain yang bermanfaat bagi kesehatan manusia; komposisinya dapat berupa bahan mentah atau bahan yang telah mengalami proses lebih lanjut yang berasal dari satu jenis tumbuhan atau lebih. (WHO, 2005; 2000).

Obat herbal telah diterima secara luas di negara berkembang dan di negara maju. Menurut WHO, hingga $65 \%$ dari penduduk negara maju dan $80 \%$ penduduk negara berkembang telah menggunakan obat herbal. Pemanfaatan jamu saat ini meningkat, baik di negara sedang berkembang maupun di negaranegara maju. Peningkatan penggunaan jamu ini memiliki dua aspek yang penting yaitu aspek medik terkait dengan penggunaannya yang sangat luas diseluruh dunia, dan aspek ekonomi terkait dengan nilai tambah yang 
Isfenti Sadalia, et al. Pendampingan Dan Peningkatan Kapasitas Dan Kualitas Produksi Jamu...

mempunyai makna pada perekonomian masyarakat.

Strategi WHO dalam hal obat tradisional mencakup empat tujuan utama yaitu (WHO, 2002) :

1. Mengintegrasikan secara tepat obat tradisional dalam sistem pelayanan kesehatan nasional dengan mengembangkan dan melaksanakan kebijakan nasional obat tradisional dengan berbagai programnya.

2. Meningkatkan keamanan (safety), khasiat dan mutu dengan memperkuat knowledgebase obat tradisional dan regulasi dan standar jaminan mutu (quality assurance standard).

3. Meningkatkan ketersediaan dan keterjangkauan obat tradisional terutama untuk masyarakat yang tidak mampu.

4. Mempromosikan penggunaan obat tradisional secara tepat oleh tenaga profesional medik maupun oleh konsumen.

Pemerintah Indonesia saat ini menggolongkan tanaman obat yang merupakan bahan baku pembuatan jamu ke dalam sepuluh komoditas potensial untuk dikembangkan. Dari sisi perekonomian, industri jamu telah berkontribusi sangat besar bagi pendapatan nasional, peningkatan kesejahteraan masyarakat dan penyediaan lapangan kerja. Bahan baku yang hampir sekitar 99\% yang digunakan merupakan produk dalam negeri dinilai mampu membawa multiplier effect yang cukup signifikan dalam pertumbuhan perekonomian di Indonesia mulai dari sektor hulu (pertanian) hingga sektor hilir yang meliputi perindustrian dan perdagangan.

Dalam aktivitas ekonominya, pasar industri jamu Indonesia telah menunjukkan pertumbuhan yang signifikan dengan nilai penjualan mencapai $\operatorname{Rp} 6$ triliun, telah menciptakan tiga juta lapangan kerja, dan dengan daerah konsumen terbesar di pulau jawa mencapai 60\% pada tahun 2007 (GP Jamu dan BPOM, 2008). Dengan keunggulan ini klaster industri jamu unggulan dapat sebagai penggerak pencipta lapangan kerja dan penurun angka kemiskinan dan atas dasar kearifan lokal dan potensi yang dimiliki produk Jamu yang berasal dari kearifan lokal. Isu perekonomian yang sedang dibangun oleh adanya MEA salah satunya adalah pengembangan usaha kecil dan menengah (Small and Medium-size Enterprises - SME) untuk mendukung pembangunan MEA.
MEA akan dijadikan sebagai kawasan yang memiliki perkembangan ekonomi yang merata, dengan memprioritaskan pada Usaha Kecil Menengah (UKM). Kemampuan daya saing dan dinamisme UKM akan ditingkatkan dengan memfasilitasi akses mereka terhadap informasi terkini, kondisi pasar, pengembangan sumber daya manusia dalam hal peningkatan kemampuan, keuangan, serta teknologi. Namun, salah satu faktor hambatan utama bagi sektor Koperasi dan UKM untuk bersaing dalam era pasar bebas adalah kualitas sumber daya manusia (SDM) dan pelaku KUKM yang secara umum masih rendah.

Di Sumatera Utara ada lebih dari 60 Usaha Kecil Obat Tradisional dan Usaha Mikro Obat Tradisional yang mungkin mencapai 100-an lebih. Perkembangan usaha kecil dan mikro ini memiliki hambatan yaitu sarana prasarana yang harus sesuai standar kefarmasian dan sistem pengemasan yang memiliki konsep yang dapat diterima pasar. Salah satu hambatan dalam pengembangan usaha obat tradisional adalah fasilitas peralatan yang dapat meningkatkan produksi obat tradisional. Selain peralatan, diperlukan juga metode standarisasi bahan baku dari hulu sampai hilir. Dalam konsep standariasasi tersebut aturan dan acuan yang digunakan dalam industri obat tradisional tersebut adalah Farmakope Herbal Indonesia (FHI). Standar yang diberlakukan dalam FHI adalah kadar air, susut pengeringan, kadar abu dan kadar sari. Selain hal tersebut, metode pengeringannya dengan menggunakan alat pengeringan yang suhunya stabil.

Mitra yang turut serta dalam pengabdian ini memiliki produk yang telah dikenal masyarakat namun belum memiliki konsep terstandar dalam produksinya sesuai dengan standar kefarmasian. Produk yang dimiliki mitra adalah Obat penurun panas dengan cara topikal yang telah digunakan oleh masyarakat sekitar. Demam atau naiknya suhu tubuh dari normal adalah penyakit yang umum diderita di masyarakat. Obat penurun panas ini dibuat dengan campuran tanaman herbal yang telah digunakan secara turun temurun dan pelarut yang digunakan adalah air. Namun, kemasan dan cara produksinya masih belum terstandar. Produksinya masih menggunakan peralatan rumah tangga seperti blender, panci, pengeringan dengan matahari dan pengisian masih secara manual dan ditakar tanpa dengan peralatan yang standar. 
Isfenti Sadalia, et al. Pendampingan Dan Peningkatan Kapasitas Dan Kualitas Produksi Jamu...

Demam bukanlah suatu penyakit, namun demam adalah suatu kondisi di mana suhu tubuh mengalami peningkatan melebihi batas normal. Batas normal suhu tubuh seseorang adalah antara $36^{\circ} \mathrm{C}-38^{\circ} \mathrm{C}$. Demam juga merupakan gejala atau indikasi seseorang sedang terserang suatu penyakit seperti batuk, flu dan pilek, radang tenggorokan, dehidrasi, serta penyakit lainnya. Demam terjadi manakala alat pengatur suhu tubuh yang dinamakan thermostat meningkatkan suhu melebihi suhu normal. Thermostat ini letaknya ada di salah satu bagian otak yaitu hipotalamus. Hipotalamus merupakan pusat pengatur temperatur tubuh, yang pada saat tertentu akan menaikkan suhu tubuh sebagai reaksi tubuh terhadap serangan suatu penyakit, kuman, bakteri, virus maupun infeksi. Dengan demikian demam merupakan bentuk perlawanan terhadap serangan infeksi, virus, bakteri atau lainnya agar para "penyerang" tersebut merasa tidak nyaman di dalam tubuh. Sehingga bisa dikatakan bahwa demam memilki manfaat bagi tubuh untuk melawan infeksi atau sebagai antivirus, karena dengan temperatur tinggi, maka daya tahan tubuh juga meningkat.

\section{II.Justifikasi Permasalahan}

Permasalahan Utama adalah :

A. Fasilitas peralatan pembuatan jamu yang saat ini dimiliki masih sangat kurang. Sehingga produsen jamu masih menggunakan alat yang sederhana dan berdampak pada proses produksi yang tidak maksimal.

B. Permasalahan kemasan yang kurang menarik sehingga konsumen tidak tertarik untuk menggunakannya.

C. Pemasaran produk yang masih terbatas pada komunitas pencinta jamu.

\section{III.Tujuan Kegiatan Pengabdian}

A. Memberikan mitra fasilitas produksi pembuatan jamu untuk membantu peningkatan proses produksi. Selain memberikan alat juga memberikan pelatihan kepada mitra bagaimana mengoperasikan peralatan tersebut.

B. Memberikan pelatihan bagaimana cara pengemasan yang baik dan menarik sehingga konsumen tertarik dan percaya dalam menggunakan jamu tersebut.

C. Memberikan pelatihan pemasaran kepada mitra sehingga calon konsumen diluar komunitas pencinta jamu herbal tertarik menggunakan jamu. Selain itu juga memanfaatkan sosial media sebagai sarana pemasaran.

\section{IV.Luaran Penelitian}

A. Penigkatan proses produksi mitra

B. Kemasan jamu mitra menjadi lebih menarik

C. Perluasan pasar sasaran.

D. Publikasi ilmiah

\section{METODE PELAKSANAAN}

Metode pelaksanaan yang diberikan dalam pengadian ini dibagikan kedalam dua tahap. Dimana tahap pertama adalah metode pelatihan dan metode kedua adalah pemberian alat. Metode pelatihan pertama adalah pelatihan penggunaan dan perawatan alat produksi ini menyangkut kepada bagaiman penggunaan dan perawatan alat-alat produksi sehingga proses produksi menjadi optimal dan penggunaan alat menjadi lebih awet.

Selain pelatihan penggunaan alat juga diberikan pelatihan bagaimana membuatan kemasan lebih menarik. Pada pelatihan ini mitra diajarkan bagaimana membuat logo produk yang menarik dan mudah diingat oleh konsumen. Selain itu, mitra juga diberikan bagaimana mengemas produk sehingga aspek higienisnya terjaga dan bagaimana kemasan tersebut memiliki nilai jual lebih pada konsumen. Adapun pelatihan yang diberikan adalah:

1. Membantu mendesain logo

2. Memberikan botol atau pengemas standar

3. Memberikan plastic pembungkus.

Mitra juga diberikan pelatihan pemasaran dalam hal ini adalah pelatihan menggunakan media sosial dalam menjual jamu. Hal ini dilakukan agar mitra dapat memasarkan produknya secara luas dan konsumen juga memperoleh produk tersebut.

Adapun metode kedua adalah metode pemberian alat produksi. Alat yang diberikan adalah sebagai berikut:

1. Alat Ekstraksi.

2. Alat Pemanas

3. Penggilingan

4. Gelas takar

\section{Evaluasi dan Monitoring}

Kegiatan ini akan dievaluasi dua bulan setelah peralatan produksi diberikan. Evaluasi dilakukan dengan mendatangi lokasi pengabdian dan melihat proses produksi. Selain itu juga akan dilakukan perhitungan jumlah produksi setiap kali produksi untuk melihat ada atau tidaknya peningkatan jumlah 
Isfenti Sadalia, et al. Pendampingan Dan Peningkatan Kapasitas Dan Kualitas Produksi Jamu...

produksi sebelum dan sesudah diberikannya peralatan. Untuk pemasaran, evaluasi dapat dilakukan setiap saat yaitu dengan melihat media sosial mitra apakah sudah ada terjadi pemesanan produk. Selain itu mitra juga akan didatangi untuk melihat ada tidaknya peningkatan jumlah volume penjualan.

Setelah kegiatan berjalan maka hasil evaluasi yang dilakukan adalah: Kegiatan Pengabdian Pada Masyarakat ini berlangsung dengan baik dan lancar, serta perlu dilakukan perbaikan dikemudian hari. Proses diskusi dan penyuluhan berlangsung dengan menarik dan para peserta sangat antusias. Hal ini ditandai dengan banyaknya pertanyaan seputar bagaimana teknik pengemasan dan bagaimana teknik menjual dengan baik. Pertanyaan yang paling banyak diajukan mitra ada pertanyaan seputar penggunaan alat produksi dan proses produksi yang terstandar kefarmasian sehingga dapat diusulkan dalam proses perizinan.

Dalam penggunaan mesin ataupun peralatan masak tim dan narasumber mengajarkan mitra bagaimana menggunakan dan merawat peralat yang ada.

\section{Partisipasi Mitra}

Mitra berpartisipasi dengan baik dan sangat antusias. Dalam kegiatan ini mitra dan tim berperan aktif dan saling bertukar ide mengenai hal-hal yang menjadi permasalahan mitra dan mencari solusi atas permasalahan yang dihadapi.

\section{Hambatan yang Dihadapi \\ 1.pengemasan dan pemasaran}

Pada tahapan ini yang menjadi kendala hanyalah bagaimana mitra memasarkan produknya kepada pihak lain. Karena produk mitra adalah obat herbal hanya sedikit orang yang mau menggunakannya dan produk mitra belum menggunakan izin edar yang jelas seperti IPRT maupun TR BPOM. Kebanyakan masyarakat masih lebih mempercayai penggunaan obat-obat pabrikan yang banyak dijual bebas.

\section{Penggunaan Sarana Produksi.}

Dalam penggunaan sarana produksi tidak ditemukan hambatan yang berarti. Yang menjadi kendala hanyalah beberapa sarana produsi yaitu alat ekstraksi yang masih belum umum digunakan mitra. Menjadi kendala dikarenakan selama ini mitra belum pernah menggunakan peralatan yang terstandar tersebut. Kendala lainnya tempat atau rumah produksi yang masih kecil sehingga proses produksi tidak bisa berjalan dengan alur kefarmasian. Tim telah menyarankan untuk dapat memperluas tempat produksi dikarenakan masih ada tempat yang masih kosong untuk dapat dijadikan tempat produksi.

\section{HASIL PEMBAHASAN KEGIATAN}

Kegiatan pengabdian pada masyarakat ini dimulai pada bulan Oktober 2016. Pada tahap ini dimulailah pra survey untuk melihat bagaimana kelanjutan usaha mitra. Pada kegiatan ini mulailah dilakukan sosialisasi Mitra usaha obat herbal pada tanggal 2 Oktober 2016 dilakukan penyuluhan dan diskusi dengan mitra bagaimana mengemas produk menjadi lebih baik dan memiliki nilai jual yang tinggi sehingga tidak kalah bersaing dengan produk pabrikan yang ada dipasar. Selain itu juga diajarkan bagaimana memasarkan produk agar lebih dikenal oleh masyarakat luas. Dan bagaimana teknik menjual dan memasarkan agar masyarakat percaya untuk menggunakan obat herbal tersebut. Pada hari yang sama kegiatan yang dilakukan selanjutnya adalah membantu mitra dalam menentukan harga jual per-unit produk. Dimana sebelumnya dalam menetukan harga jual mitra tidak memiliki acuan yang jelas. Kondisi tersebut yang menyebabkan mereka sering mengalami kerugian. Dan dalam pelabelan maupun packaging diberikan saran dan desain yang kedepannya dalam hal komposisi yang jelas, klaim khasiat, bentuk packing seperti botol dan lainnya. Untuk produk-produk dalam bentuk kapsul, tim menyarankan mitra untuk memproduksi dalam skala terbatas untuk menghindari produk dijual dalam toko resmi. Hal ini dikarenakan produk kapsul belum disarankan untuk produksi ditingkat Usaha Mikro namun dalam bentuk Usaha Kecil. Namun, untuk permasalah tersebut Tim Pegabdian telah memberikan solusi untuk kedepannya meningkatkan atau menaikkan grade usaha dari Usaha Mikro menjadi Usaha Kecil dengan saran memperluas ruang produksi yang standar. Dalam hal lainnya, Tim Pengabdian memberikan penyuluhan dengan konsep higienis dan sanitasi dalam produksi obat tradisional. 
Isfenti Sadalia, et al. Pendampingan Dan Peningkatan Kapasitas Dan Kualitas Produksi Jamu...

Pada tanggal 2 November 2016 Tim pengabdian pada masyarakat Universitas Sumatera Utara kembali mendatangi dan membina mitra. Pada tahap ini tim mulai menilai kemajuan yang diperoleh mitra binaan dalam hal produksi dan pemasaran. Selain itu untuk meningkatkan hasil produksi maka Tim pengadian pada masyarakat menyerahkan beberapa alat untuk menunjang kegiatan produksi. Alat yang diberikan diharapkan dapat meningkatkan volume produksi, dan membuat hasil produksi menjadi lebih baik dengan lebih memperhatikan konsep higienis dan sanitasi. Pada tahapan ini mitra juga diajarkan cara penggunaan peralatan yang baru.

\section{Teknik pengemasan dan pemasaran produk.}

Teknik pengemasan yang baik akan membantu mitra dalam memasarkan produk dengan lebih baik dan juga kebersihan produk akan terjaga. Pengemasan dengan konsep kemudahan bagi konsumen diajarkan seperti produk oles yang sebelumnya menggunakan botol biasa diganti dengan botol oles khusus dan Serbuk instan dengan konsep resealing atau ditambahkan pembungkus tambahan di dalam plastik pembungkus luar. Selain itu mitra juga diajarkan bagaimana memasarkan produk dengan memanfaatkan jaringan mereka miliki. Dimana pengguna obat herbal memiliki komunitas pencinta obat herbal. Oleh sebab itu mitra diharapkan dapat memasarkan obatnya kepada komunitas tersebut sehingga diharapkan komunitas tersebut akan meneruskan kepada kerabat yang lain dan juga kepada pihak ketiga lainnya (Konsep Pemasaran secara Kekeluargaan). Disamping itu mitra juga diberikan penyuluhan mengenai konsep berusaha Legal Bisnis yaitu konsep usaha agar produk mereka dapat memasuki toko toko obat tradisional yang lebih besar.

\section{Penggunaan Sarana Produksi.}

Dalam memproduksi produk jamu atau obat tradisional ini, Mitra usaha masih menggunakan alat yang sederhana dan dengan kapasitas yang kecil. Sehingga produk yang dihasilkan juga sangat sedikit. Untuk membantu mereka dalam memproduksi produk menjadi lebih banyak maka Tim Pengabdian Pada Masyarakat Universitas Sumatera Utara memberikan peralatan berupa:

1. 2 unit kompor listrik
2. 1 paket mesin ekstraksi / perkolasi

3. 1 unit penggilingan

4. 1 unit timbangan digital

5. 1 unit Thermometer IR

6. Peralatan Gelas Laboratorium

Pemberian alat ini diharapkan dapat meningkatkan volume produksi dan memberikan konsep produksi standar farmasi secara sederhana/kecil. Pada awalnya produksi obat tradisional masih secara konvensional menggunakan peralatan dapur. Pelarut yang digunakan pada mitra dalam mengekstraksi tanaman obat adalah alkohol dengan konsentrasi $70 \%$ dan 96\%. Setelah proses ekstraksi Mitra menguapkan larutan ekstrak dengan menggunakan panci dengan pengadukan sehingga alcohol menguap di udara. Hal ini bisa membahayakan mitra karena uap alkohol dapat memberikan efek merugikan pada mitra seperti pengaruh pada organ hati dan pernafasan. Alkohol seharusnya dapat didestilasi (dicairkan kembali) dengan menggunakan ekstraktor khusus sehingga uap alkohol dapat dicairkan dan dipergunakan kembali. Proses ini yang disebut dengan green system, dimana proses penggunaan kembali pelarut yang sebelumnya digunakan dalam tahapan produksi dapat memangkas biaya produksi sehingga Mitra mendapatkan keuntungan lebih. Alat yang diberikan kepada mitra berupa alat ekstraksi dan pendinginan uap dengan kapasitas 10 liter dapat dipergunakan untuk menghasikan ekstrak murni dengan hasil terstandar farmasi. Alat tersebut menggunakan stainless dengan grade farmasi (Stainless 304). Alat ekstraksi ini dimodifikasi dengan konsep dapat digunakan industri obat rumah tanggal (Usaha Mikro Obat Tradisional/UMOT). Selain alat eksraksi, Tim pengabdian memberikan alat penggilingan dengan standar food grade sehingga hasil produk yang dihasilkan lebih baik. Penggilingan ini memiliki kapasitas Home Industri (Produksi Mini). Peralatan penunjang lainnnya seperti kompor listrik yang dipergunakan untuk memanaskan alat pengekstraksi diberikan untuk mencegah penggunaan kompor minyak yang menghasilkan asap sisa pembakaran, thermometer IR yang dipergunakan untuk memeriksa proses penguapan atau pemanasan produk sehingga suhu dapat menjadi standar dalam proses produksi, alat gelas laboratrorium untuk memberikan takaran bahan aktif dengan akurat, timbangan digital untuk menimbang bahan-bahan secara akurat dan terstandar serta peralatan sanitasi dan 
Isfenti Sadalia, et al. Pendampingan Dan Peningkatan Kapasitas Dan Kualitas Produksi Jamu...

higinis seperti sarung tangan dan masker sehingga proses produksi dapat berjalan dengan standar kefarmasian.

\section{KESIMPULAN DAN SARAN}

\section{Kesimpulan}

Dari hasil pengabdian masyarakat yang dilakukan dapat diambil kesimpulan sebagai berikut:

1. Dari hasil penyuluhan dan pelatihan kepada Mitra, maka telah terbentuknya sistem produksi yang terstandar dengan menggunakan fasilitas peralatan yang standar dan baik sesuai dengan standar kefarmasi (UMOT)

2. Produk obat tradisional yang dihasilkan Mitra dapat diterima pasar lebih baik dan sudah memiliki konsep kemasan yang lebih baik dan diterima pasar seperti pada konsep packaging, perubahan bentuk botol, dan kemasasan.

3. Fasilitas peralatan ekstraksi yang telah diberikan kepada Mitra dengan konsep Green System telah dapat meningkatkan kemampuan Mitra UMOT baik dalam produksi jamu maupun obat tradisional dan kedepannya dengan fasilitas tersebut maka mitra dapat melakukan pengurusan proses birokrasi (perizinan dan registrasi) untuk dapat meningkatkan pemasaran dan promosi produk herbal.

\section{Saran}

1. Diharapkan kepada mitra dengan telah diberikannya alat pembuatan ekstrak tersebut maka dapat melakukan proses perizinan ke Instansi terkait sehingga kedepannya usaha mitra dapat lebih baik

2. Diharapkan Mitra dapat menjadi Mitra Strategis Tim Pengabdian dalam pengembangan obat tradisional dikarenakan banyaknya potensi dari mitra dalam mengembangkan ramuan obat tradisiona

\section{DAFTAR PUSTAKA}

WHO, 2005. National Policy on

Traditional Medicine and

Regulation of Herbal Medicines, Report of a WHO global survey, Geneva

WHO. 2002. Traditional Medicine Growing Needs and Potential.Geneva

WHO. 2002. WHO Traditional Medicine Strategy. Geneva. 